\title{
Determinants of Audit Opinion after the Scandals of Enron: Empirical Validation in the French Context
}

\author{
Soltani Lynda ${ }^{1}$ \\ 1 Faculty of Law, Economics and Management, University of Jendouba, Tunisia \\ Correspondence: Soltani Lynda, Faculty of Law, Economics and Management, University of Jendouba, Tunisia. \\ E-mail: lynda_soltani@yahoo.fr
}

Received: February 10, 2016

Accepted: March 14, 2016

Online Published: April 18, 2016

doi:10.5539/ijbm.v11n5p219

URL: http://dx.doi.org/10.5539/ijbm.v11n5p219

\begin{abstract}
This study examines the effect of regulatory changes on audit quality in the French context. The evaluation of the risks and the anomalies carried out by the auditors brings them control relating to the financial statements of the company in order to express an opinion on the effectiveness, the regularity, the sincerity and the faithful image of these documents, in a large complexity of the organizations the objective of this research consists in studying the effect of the evolutions of the regulation as regards legal audit on the estimate of the probability of having an opinion of audit with reserve which reinforces the independence of the auditor.

A list of hypothesis related to the approached problems is proposed followed by an overview of the different theoretical propositions which are in place. From a sample of French companies in the SBF 250 over the period 2002-2011, the results show that the analysis of the conditions of receiving a qualified audit opinion is determined by: the variables of the financial health of the company, the inventory receivables which indicate the complexity of the audited firm and the characteristics of the audit.
\end{abstract}

Keywords: regulation, auditing qualified opinion, abnormal audit fees, audit quality

\section{Introduction}

The role of the financial information and the accountant is very important to ensure the good performance of a firm, so it is necessary to reinforce the modes of controls while being based on the regulation and the modernization of operation of the auditor in order to achieve his mission under the best conditions by ensuring responsibility for the certification of their opinion.

In 2002, Carol Lambert and Claude Cazes find that: "The Enron business asked the question of the reliability of the information given to the thirds about the accounts of a company and that of the guarantee that the audit as for the sincerity of these accounts brings. The American system has faults which precipitated the fall of the company, but evolutions to improve the standards and controls are desirable both in Europe and in the United States.

Reforms are moving as regards international harmonization of the countable standards and applicable rules, of development of controls within the companies, independence and competence of the auditors and the external administrators." (Note 1).

The increasing instability of the environment, the increasingly large complexity of the organizations and the increasingly strong interdependence of their activities encourages the appearance of the management of results aiming for the covering of the visibility of the weak performances with the company for that the evolution of the accounting standards authorizes the evolution in mode of control in order to slow down these operations by improving the quality of the financial and accounting information.

For this purpose, the literature shows that the evolutions of the accounting standards and the emergence of the new regulations are adopted in order to improve quality of audit and to control the management of result operations in order to obtain a good system of governance. Also that the central role of the audit is the management of the discretionary decisions of the leaders and their influences on the contents of the financial statements while confronting the independence of the auditor, because while referring to the international standards of audit one finds that the auditor must express his opinion with reserve in a situation which limits the development of its tasks. 
For this reason one thinks that it constitutes a base of control within the companies in an environment changing like this last become a key factor of the success of the company.

For is that our fundamental question to know which are the determinants which predict the probability of the formulation of an opinion of audit with reserve?

\section{Literature Review}

The existence of the financial scandals revealed in the United States in 2001, exerted a loss of confidence in the financial markets. The American answer was the Sarbanes Oxley law. At the same time when France set up this security act in 2003 .

Pascale Revault in 2010 (Note 2) found that after the scandal of Enron, as well as the poor results with the fall of Andersen, the fascinating relationship created beforehand will be qualified by a lack of confidence and concern towards the reliability of the financial information. Because of this, the births of new laws were necessary in the United States, first, and then in Europe, in order to best guarantee procedures to have a good environment of control within the companies.

The Law of Financial Safety takes as a starting point the Sarbanes Oxley Law in order to regulate the systems of governance of the company by controlling the internal and external audits and to modernize the institutions which moderate the transformation of the profession of the comptroller of the accounts during oversight by reflecting the faithful image of financial and accounting information.

\subsection{The Modernization of the 8th Directive}

The 8th Directive is a European directive related to the control of the accounts which requires a certain number of regulations of the profession of the auditor. Its objective is the improvement of criterion of legal independence of the inspector in a qualified volatile environment of the insufficiencies and failures of the modes of control.

The modernization of the 8th Directive fixed the importance of the independence of the auditor in order to achieve his mission in full safety and by guaranteeing the transparency of the financial information.

Then, the directive founded rules concerning the composition of the audit committee and requires independence of its members, since it has as its main mission the internal follow-up of the monitoring systems of the firm thereby ensuring its effectiveness.

Moreover, it obliges the auditors to undergo training in order to improve their skills and the quality of their works which indicates that the modernization of the 8th Directive has the goal of the evaluation of the quality of the legal profession of the comptroller by laying out rules of improvement of their mission and the reinforcement of their responsibility.

Lastly, the professional evolution of the comptroller obliges them to be ready to verify during the checks of the accounting irregularities and by behaving independently in order to be responsible and to carry out their mission in accordance with the standards.

\subsection{The Audit Profession}

The reduction of the risk of the reliability of the financial information is regarded as being the principal question of the independence of the auditor and more generally of the quality of audit.

All these circumstances oblige the auditor to achieve his work in accordance with the standards while creating an independent examination and financial and internal monitoring systems by justifying the accounting practices carried out on the audited level of the firm. Thereafter its work will be completed by the formulation of an auditor's report which differs from others according to the checks carried out.

In order to achieve his main mission the independent auditor must express his opinion on the financial statements of the company audited in accordance with the international standards of audit.

The objective of the audit of the financial statements is to carry out a level of reliability, credibility and of confidence of the financial documents and more generally of the performance of the company.

Indeed, on the one hand the responsibility the auditor obliges to him to check for errors and fraud by evaluating the incidences of the risks of the company and by becoming acquainted with its environment.

In addition, the checking of internal control represents one of the important stages of the audit of the financial statements by ensuring the transparency of the financial information and by detecting the anomalies. Thereafter, the auditor must express his opinion in their report. This constitutes a significant component so that the users of the financial information can make a good decision. 
Following the financial statement audit, it is important that the auditor expresses his opinion in an auditor's report. This constitutes a manner for the shareholders of the company of making sure of the relevance of the accounting information.

An independent auditor must write an exhaustive report of the oversight of the financial statements. It is essential that they follow a certain number of procedures in order to check that if the record keeping and finances are lacking significant anomalies. If it is the case, the auditor certifies an opinion without reservations by expressing the faithful image of the financial statements.

However, and in accordance with the standards of auditing in the contrary case, a modified opinion report also expresses reservations presented like a warning in order to avoid fraud and errors on the level of the financial statements. This qualifies its independence by moderating its opinion in a complex and turbulent environment.

There are three principal types of modified audit opinions: quoting with reservations, the unfavourable opinion and the case of the impossibility of expressing an opinion.

$\checkmark$ Qualified opinion: The auditor certifies an opinion with reservations when they find significant inaccuracies and anomalies but not precise on the level of the financial documents,

$\checkmark$ Adverse opinion: The auditor certifies an unfavourable opinion when they find significant inaccuracies and anomalies on the level of the financial documents,

$\checkmark$ Disclaimer of opinion: The auditor cannot certify an opinion when they do not find evidence so that they are able to constitute and express their opinion.

\subsection{Determinants of the Opinion of Audit Modified}

Jietong Chen, Douglas Cumming, Wenxuan Hou and Edward Lee (2013) take as a starting point the literature and advance that: when the independence of the audit became essential for the function of the auditors (Xiang, 1998), of the Chinese studies concentrate mainly on this point. DeAngelo (1981), Yang et al. (2003), Krishnan et al. (1996) which relates to the modified audit opinions like a very important instrument for the independence of the auditors. Until the year 1990, the independence of the audit in China was a great concern because the auditors played the part of agents of the office of control of the State and had little economic responsibility for their inappropriate actions of audit, in their customers' interests or in their own interests (DeFond et al., 2000; Yang et al., 2001). (Note 3).

The researchers find that a modified opinion audit is an important demonstration of various results of audit and the audit quality as it advances (Francis, 2004) and, in general receives great attention of the auditors, the investors and the public (Chen, Su, and Zhao, 2000; Chow and Rice, 1982; Dopuch, Holthausen, \& Leftwich, 1986). Thus, a modified opinion audit is largely used like an indicator of the audit quality, at the same time in the literature of the audit (for example, Chow \& Rice, 1982; Craswell, Stokes, \& Laughton, 2002; Krishnan, 1994; Lennox, 2005) and in studies related to China (Chan, Flax, \& Mo, 2006; Chen, Chen, \& Known, 2001; Chen et al, 2010; Wang et al., 2008). Also see Chen et al (2000, 2001), Chen et al. (2010) and Wang et al. (2008). (Note 4).

The literature consists of the variable cuts as a variable of control which is represented like an explanatory factor of the opinion with reservations of the auditor. Concerning the financial health of the company, one finds that several studies relate to the effect of the output of the firm on the quality of the audit opinion. In this direction, Fang and Hong (2008) which advances that the abnormal output of the credits encourage the auditors to formulate an audit opinion without reservations. In the same way, the results of Zanchun, Chun Cai, and Jianming Ye (2010), shows that, the companies with a strong increase in profitability are associated with a better audit opinion.

All the more Yoke-Kai Chan and Terry S. Walter (1996) (Note 5) advances that the indicator of liquidity informs on the capacity of the company to answer its obligations. Nelson et al. (1988) show that the effort of the auditors increase with the increase in risk of the customer. Consequently, the qualifications of the audit opinion should be a negative function of the liquidity of the company.

Yoke-Kai Chan and Terry S. Walter (1996) find that higher levels of debt imply the increase in the financial risk of the company and consequently the auditors are incited to be more attentive in their functions. However, if the financial situation of the company continues to drop, the solutions of accountancy become increasingly difficult to discover. In such circumstances, the auditor imposes an audit opinion with reservations. As a variable of control, one adds the variable loss because Craswell (1999), finds that the firms which announce a loss will be riskier at the financial level than that of the exploitation. 
Then in regards to the complexity of the customer company customer, Michael Firth, Oliver Mr. Rui and XiWu in 2012 (Note 6) expect that these variables are positively associated with the frequency of reception of the audit opinions with reservations.

In the end, the characteristics of the audit can be summarized on the one hand in the identity of the auditor one finds. Yoke-Kai Chan and Terry S. Walter (1996) add that the large bureaus of audit approve a higher level of checking compared to the small (Francis \& Stokes, 1986; Nelson et al., 1988). These considerations are used to think that the large companies are more likely to qualify a report of audit to protect their reputation.

In addition, the audit opinion of the previous year, Monroe and Teh (1993), (Note 7) show that the existence of a modified audit opinion for the previous year increases the probability of qualified certification of the accounts, because the uncertainty created in one year is likely to exist in the following years. In addition, the abnormal audit fees that Zanchun, Chun Cai, and Jianming Ye (Note 8) examined in 2010 show that a company with dimensions can obtain a better audit opinion by paying expenses of superior checking on its normal level. By using the data of the markets of the capital of China over the period 2002-2008, these authors examined the increase in the audit fees and their assistance of the companies to reach a better audit opinion or at least not to be given an unfavourable opinion.

The objectivity and the independence of the auditors are more likely to be influenced by the level of the customer's fees beyond that of the auditors on the normal expenses, expenses rather than expected the normal level of expenses which reflects mainly the costs of the efforts of the auditors. If an auditor receives fees abnormally (positive abnormal expenses), these positive abnormal expenses influence the dependence of the auditor, and thus the deterioration of the audit quality.

DeAngelo (1981a), Frankel et al (2002) of the study note that a strong economic link between the auditor and his customer will make it possible to reduce the quality of the results published by the decrease in the will of the auditors to camouflage the errors of accounting information announced. Beck, Frecka and Solomon (1988) report that the economic connection of an inspector to the customers increases as the auditor receives higher customer fees and the auditors's independence thus fades. (Note 9).

\section{Theoretical Framework}

The objective of this research consists in studying the determinants of the audit opinion as an element which checks the audit quality. More particularly, it is a question of identifying the bond between the variables which all the more influence the mission of the auditor by formulating his audit opinion as a criterion which measures its level of independence from the audited company, one must empirically validate the determinants of the formulation of the auditor opinion and their impact on his independence from the French companies.

The type of opinion certified by the auditor is constituted like a signal of the audit quality and more particularly of its independence. This signal can satisfy the user's needs with the financial information. For this purpose it is necessary to analyze economic determinants to announce the financial health of the company, like its performance on the market and other determinants which give information about the characteristics of the auditor by reflecting the image of the independent auditor.

At the conclusion of the former results of the studies, and following the structuring of the new regulations, we formulate the assumptions which will be tested as follows:

The financial statement of the company; we admit the following assumption:

$\mathrm{H} 1$ : the probability of receiving an audit opinion with reservations is associated with the financial statement of the company.

-Abnormal outputs of the company (reduction in disruptions);

-Liquidity of the company (reduction in disruptions);

-Debt of the company (increase in disruptions);

- The loss of result of the company (increase in disruptions).

In the second place, other economic variables inform about the level of complexity of the customer company which contributes a positive bond with the probability of obtaining an audit opinion with reservations.

$\mathrm{H} 2$ : the probability of receiving an audit opinion with reservations is associated with the complexity of the company.

- The inventory turnover of the company; 
-The rotation of the clients' account of the company.

H3: the probability of receiving an audit opinion with reservations is associated with the characteristics of the auditor.

- The existence of a Big 4 auditor (positive association);

- The existence of a modified audit opinion from the previous year (positive association);

- Abnormal audit fees perceived by the company (negative association).

Finally, the organisational factor of company size which is in positive relationship to the probability of receiving an audit opinion with reservations, our last assumption is the following one:

H4: the probability of receiving an audit opinion with reservatuins is positively associated with keeping the company.

$$
\begin{gathered}
\text { OPINION }_{i t}=\beta_{0}+\beta_{1} \Delta R O A_{i t}+\beta_{2} \text { LIQUI }_{i t}+\beta_{3} D E B T_{i t}+\beta_{4} \text { LOSS }_{i t}+\beta_{5} I_{N V E N T_{i t}}+\beta_{6} \text { RECEIV }_{i t}+\beta_{7} \text { BIG }_{i t}+ \\
\beta_{8} \text { OPINION }_{i t-1}+\beta_{9} A B F E E_{i t}+\beta_{10} \text { SEIZE }_{i t}+\varepsilon_{i t}
\end{gathered}
$$

\subsection{Dependant Variable}

The dependant or variable to explain is defined by the probability of obtaining an audit opinion with reservations by reflecting the criterion of the independence of the auditor while generally supporting the audit quality from where one finds:

OPINION: binary variable which takes value 1 if company I receives an audit opinion with reservations and 0 if not.

\subsection{Independents Variables}

$\triangle \mathrm{ROA}:$ Change in ROA, where ROA is net income divided by total assets at the beginning of the year LIQUI: working capital ratio is the relationship between the short-term credits of a company to its passive in the short run.

DEBT: Rate of debt, total report of the debts and total credit.

LOSS: this variable is a binary variable coded by 1 if it exists as a countable loss during the exercise and 0 if not. It is equal to 1 if the company has a negative bottom line and to 0 if the company has a positive bottom line.

INVENTORY: ratio of inventory turnover measured by the relationship between the cost of the sold goods and stocks of the company.

RECEIVE: ratio of receivable turnuver measured by the relationship between the credit sales and the clients' accounts of the company.

BIG: binary variable coded 1 if the audit office within the customer company belongs to the "BIG" and 0 if not OPINIONt-1: binary variable which takes a value of 1 if company I receives an audit opinion of with reservations of year T- 1 and 0 if not.

ABFEE: abnormal fees of audit defines by Fang and Hong (2008),

$\Delta \mathrm{Ln}($ Fee/Assets $)=\operatorname{Ln}\left(\right.$ Audit Fee $_{\mathrm{t}} /$ Assets $\left._{\mathrm{t}}\right)-\mathrm{Ln}\left(\right.$ Audit Fee $_{\mathrm{t}-1} /$ Assets $\left._{\mathrm{t}-1}\right)$.

SIZE : Company size, Napierian logarithm of the active total.

cit: the term of error and the $\beta$ i are the coefficients to be estimated.

\section{Empirical Research}

\subsection{Research Methodology}

On the level of our study we seek the relationship between the variables which have an effect on the opinion of the auditor as a criterion which measures its level of independence.

This study more particularly lies within the scope of accounting research the criterion of audit independence.

Our research requires an empirical approach while following the econometrics of a given panel. For that, it is essential that all the types of analysis start with some basic statistics by calling for descriptive statistics.

All the more, the dependant variable is a binary variable ranging between 0 if pure and simple certification and 1 if it is with reservations resulting from a predictive model which requires an analysis with a logistic regression since it represents one of the statistical techniques making it possible to establish a relationship between a 
variable to be explained and explanatory variables, by studying the relationship between them and to make forecasts using software STATA 10.

\subsection{Data Collection}

The population concerned is made up by the indices SBF 250 (118 companies) of which part of information are available on the basis of data Thomson one and the other part coming from the reference documents and the annual reports located on the website www.zonebourse.com. These companies were observed over one 10-year period from 2002 until the year 2011 which is the period around the events of the study. These events took place during the years 2002 for the period post Enron and 2003 for the emergence of the regulations law LSF. Moreover, the countable data relating to the French companies were elaborating according to the French local standards for the period between 2002 and 2004, and in international standards IFRS for the period between 2005 and 2011.

Table 1. Sample composition

\begin{tabular}{llll}
\hline Étapes & Nombre des sociétés éliminées & $\begin{array}{l}\text { Nombre } \\
\text { restantes }\end{array}$ & des sétés \\
\hline Échantillon initial (SBF 250) & & 250 \\
Élimination des établissements financiers & 38 & 212 \\
Élimination des sociétés faute de rapports annuels & 19 & 193 \\
Élimination des sociétés faute de publication des & 41 & 152 \\
honoraires d'audit & 34 & 118 \\
$\begin{array}{l}\text { Données manquantes } \\
\text { Échantillon final }\end{array}$ & 118 & \\
\hline
\end{tabular}

\subsection{Data Analysis}

On the level of this stage, one passes from an analysis which describes in detail our variables via a descriptive technique with another exploratory analysis of the effectiveness of the results carried out on the determinants of the probability of receiving an audit opinion with reservations. This is why this section is broken up into two small sections: the first that of the plain-varied analyses and the multivariant analyses in the second section.

Table 2. Descriptive statistics

\begin{tabular}{llllll}
\hline Variables & Nombre d'observations & Moyenne & Ecart type & Min & Max \\
\hline Opinion & 1180 & 0.2118644 & 0.4088025 & 0 & 1 \\
size & 1180 & 7.157921 & 2.278438 & 1.790091 & 12.12502 \\
rroa & 1180 & -0.014839 & 6.690594 & -56.96 & 55.8 \\
Liquid & 1180 & 1.5025 & 1.182536 & 0.31 & 14.74 \\
Debt & 1180 & 23.54178 & 15.79558 & 0 & 110.24 \\
Loss & 1180 & 0.3025424 & 0.4595535 & 0 & 1 \\
Receiv & 1180 & 36.50547 & 331.0441 & -8.07 & 8996.4 \\
Invent & 1180 & 5.170127 & 11.1726 & 0.27 & 373 \\
Big & 1180 & 0.7720339 & 0.4196985 & 0 & 1 \\
opinion_n-1 & 1180 & 0.2101695 & 0.4076016 & 0 & 1 \\
Abfee & 1180 & -0.0170363 & 0.4044027 & -4.41864 & 4.214652 \\
& & & & & \\
\hline
\end{tabular}

This table of descriptive statistics of our sample shows the following results:

It is observed that starting from 118 observations of the French companies during one ten-year period from 2002 to 2011, the statistical dispersion of the variables:

We can release from our dependent variable, which is a binary variable varies between 0 and 1 tested out of 118 companies of our sample of SBF 250 that only $21 \%$ reports an audit opinion with reservations on financial statements carried out according to new regulations and accounting professional standards, with a standard deviation of 0.40 , which shows that there are few companies which formulate an opinion with reservations and more particularly an opinion which reflects the level of auditor independence. 
Table 3. Logistic regression

\begin{tabular}{|c|c|c|c|c|c|c|c|c|}
\hline Variables & & Coefficients & Std. error & $\mathbf{Z}$ & $\begin{array}{l}\text { Sig } \\
\mathbf{P}>|\mathbf{Z}|\end{array}$ & Odds ratio & $\begin{array}{l}\text { predicted } \\
\text { sign }\end{array}$ & $\begin{array}{l}\text { sign } \\
\text { obtained }\end{array}$ \\
\hline size & & -.0721187 & .0594236 & -1.21 & 0.225 & .9304204 & + & - \\
\hline$\underline{\Delta r o a}$ & & -.0201677 & .0121127 & $-1.66^{* * *}$ & 0.096 & .9800343 & - & - \\
\hline Liquid & & -.3470757 & .1571827 & $-2.21 * *$ & 0.027 & .7067518 & - & - \\
\hline Debt & & .0169719 & .006979 & $2.43 * *$ & 0.015 & 1.017117 & + & + \\
\hline Loss & & .0009262 & .2031676 & 0.00 & 0.996 & 1.000927 & + & + \\
\hline Receiv & & -.0003457 & .0004055 & -0.85 & 0.394 & .9996544 & + & - \\
\hline Invent & & .0242056 & .0109166 & $2.22 * *$ & 0.027 & 1.024501 & + & + \\
\hline Big & & .7298328 & .3060231 & $2.38 * *$ & 0.017 & 2.074734 & + & + \\
\hline opinion_n-1 & & 1.433314 & .2142916 & $6.69^{*}$ & 0.000 & 4.192572 & + & + \\
\hline Abfee & & .1217219 & .210275 & 0.58 & 0.563 & 1.12944 & - & + \\
\hline Cons & & -2.079883 & .5355697 & $-3.88 *$ & 0.000 & & & \\
\hline $\operatorname{lnsig} 2 \mathrm{u}$ & & -.2178754 & .378053 & & & & & \\
\hline sigma_u & & .8967863 & .1695164 & & & & & \\
\hline Rho & & .1964356 & .0596751 & & & & & \\
\hline Number & of & 1180 & 1180 & 1180 & 1180 & 1180 & & \\
\hline \multicolumn{9}{|l|}{ Observations } \\
\hline $\operatorname{Chi}^{2}(10)$ & & 81.11 & 81.11 & 81.11 & 81.11 & 81.11 & & \\
\hline Prob $>\mathrm{Chi}^{2}$ & & 0.0000 & 0.0000 & 0.0000 & 0.0000 & 0.0000 & & \\
\hline
\end{tabular}

$*, * *, * * *$ : Significatif respectivement aux seuils de $1 \%, 5 \%$ et $10 \%$.

This kind of model requires the use of the Total Test of Significativity of Wald in order to assess the quality of the estimate which is carried out. As the results of the table indicate, from 1180 observations our estimated model is overall significant.

Indeed, the P-Been worth Test of Wald Chi 2 to 10 degrees of freedom is about 81.11 and of total significativity of the model is of 0.0000 lower than the threshold of $5 \%$. Thus for this threshold, the worthless assumption Ho of equality to 0 of the constant and the estimated coefficients is rejected and thus the existence of a significant variation in the probability of receiving an audit opinion with reservations.

The second stage of analysis of our probabilistic model resides to make the examination of the total coefficient of correlation, indeed with 118 Rho observations has the order of 0.2 the test of the report of probability by determining the variance of the panel which allows us to reject the worthless Rho assumption equalizes to 0 , which proves that there exists a heterogeneity not observed. Aditionally, the presence of the individual effects is announced. Indeed, the indication of Rho $=0.2$. What reveals that approximately $20 \%$ of the total variability of the model is explained by individual effects.

The continuation of the work of analysis will be generated by the test of the report of probability on the estimate for random purpose

We present in this part the empirical results found using our econometric model presented as above, by using in the first place the model xtlogit with option RE and while treating the given with the software STATA version 10 which gives us results of coefficients of the variables of model, one passes in the second place to the model xtlogit with option OR in order to have the odds ratios to analyze ratios of probability of receiving an audit opinion with reservations.

We note that the signs of the coefficients estimated for the pluparts of our variables are similar to those expected. A plus coefficient increases the probability, while a negative value decreases the probability predicted.

The table presents the coefficients of the various variables and the reports of OR (odds ratios) combined to our variables. To the level of the analysis of result of our Logit model, the estimated coefficient of an explanatory variable indicates only the direction of the relation which exists between this variable and the explanatory variable. It is then usual to analyze and interpret the reports of chance to appreciate the impact of each explanatory variable on the explanatory variable. 


\subsection{Variables of the Financial Health of the Company}

\subsubsection{Abnormally Profitability of the Company}

The examination of the table above indicates that the abnormal output variable of the $\Delta$ roa_company has an odds ratio equal to $0.98<1$ i.e. the output of the company decreases the probability of receiving an audit opinion with reservations of $2 \%$, which shows a weak association between these two variables.

Moreover, the coefficient associated with the $\Delta$ roa variable is negative of -0.02 very weak and significant with the threshold of $10 \%$ with $(\mathrm{P}=0.09)$ This result is coherent with the results of the studies Fang and Hong (2008) and Zanchun, Chun Cai and Jianming Ye (2010) which showed that the abnormal output of credits encourages the auditors to formulate an audit opinion without reservations and consequently negatively influence the probability of having an audit opinion with reservations.

\subsubsection{Liquidity}

The examination of the table above indicates that the liquid variable has an odds ratio equal to $0.70<1$ i.e. the working capital ratio of the company decreases the probability of receiving an audit opinion with reservations of $30 \%$ which shows a weak association between these two variables

Or that means that the increase in the standard deviation of this factor of unit decreases the probability of receiving an audit opinion with reservations of $30 \%$.

Moreover, the coefficient associated with the liquid variable is negative of -0.35 and significant with the threshold of $5 \%$ with $(\mathrm{P}=0,027)$ This result is coherent with the results of the studies (Yoke-Kai Chan and Terry S. Walter 1996 and Nelson et al in 1988) which showed that the efforts of the auditor increase with the increase in the level of risk and decreases in the least risky companies with strong liquidities that can incite the auditors to certify their opinions without reservations and consequently positively influence the probability of having an audit opinion with reservations.

\subsubsection{Debt}

The examination of the table above indicates that the debt variable has a odds ratio equal to $1.02>1$ i.e. the decision of certification of an audit opinion with reservations is of 1.02 times more chance of occurs.

Or that means that the increase in the standard deviation of this factor of debt of unit increases the probability of receiving an opinion of audit with reserve of $2 \%$.

Moreover, the coefficient associated with the variable debet is positive of 0.02 and significant with the threshold of 5\% with $(\mathrm{P}=0,015)$ This result is coherent with the results of the studies (Dopouch and Al in 1987, Yoke-Kai Chan and Terry S. Walter in 1996 and Nelson et al 1988) which showed that higher levels of debt imply an increase in the financial risk of the company and consequently the auditors are incited to be more attentive in their functions that can incite the auditors to certify their opinions with reservations and consequently positively influence the probability of having an audit opinion with reservations.

\subsubsection{Loss}

The examination of the table above indicates that the loss variable has a odds ratio equal to 1, i.e. the loss of the company is independent of the probability of receiving an audit opinion with reservations which shows that there is not an association between these two variables.

Moreover, the coefficient associated with the loss variable is equal to 0 and nonsignificant with $(P=0.99)$ This result is not coherent with the results of the studies (Craswell, 1999, and Ashton et al, 1987) which showed that the auditors are more careful during the process of audit for a loss announced to the level of the company and thus it estimates that the loss of the company increases the probability of financial failure, thereafter this variable is strongly associated to formulate an opinion with reservations and consequently, positively influence the probability of having an audit opinion with reservations.

\subsection{Complexity of the Customer Company}

\subsubsection{Inventory Turnover}

The examination of the table above indicates that the inventory turnover variable of the company invent has an odds ratio equal to 1, i.e. the ratio of stock renewal is independent of the probability of receiving an audit opinion with reservations which shows that there is no association between these two variables.

Moreover, the coefficient associated with the invent variable is equal to 0 , and nonsignificant with $(\mathrm{P}=0,394)$. This result is not coherent with the results of the former studies on the basis of the United States database or 
Australia, but is compatible with the base of China (for example, Wang et al, 2008). In our sample, the invent variable is correlated negatively with the explanatory variable, in former studies (for example Craswell et al in 2002), this ratio indicates the complexity of the company and can be strongly associated with the audit risk in our case this ratio negatively influences the probability of having an audit opinion with reservations.

\subsubsection{Receivables Turnover}

The examination of the table above indicates that the receiv variable has an odds ratio equal to $1.02>1$, i.e. the decision of certification of an audit opinion with reservations is 1.02 times more likely to occur.

Or that means that the increase in the standard deviation of this factor of ratio of rotation of the clients' account of a unit increases the probability of receiving an audit opinion with reservations of $2 \%$.

Moreover, the coefficient associated with the receiv variable is positive of 0.02 and significant with the threshold of 5\% with ( $\mathrm{P}=0,027)$. This result is coherent with the results of the studies (Chen et al, 2001; Craswell et al, 2002; DeFond et al, 2000 and Krishnan, 1994) which showed that the increase in the level of company complexity implies the increase in the financial risk of the company and consequently the auditors are incited to be more attentive in their functions that can incite the auditors to certify their opinions with reservations and consequently positively influence the probability of having an audit opinion with reservations.

\subsection{Characteristics of the Audit}

\subsubsection{Identity of the Auditor}

The examination of the table above indicates that the big variable has an odds ratio equal to $2.07>1$ i.e. the decision of certification of an audit opinion with reservations is 2.07 times more likely to occur.

Or that means that the increase in the standard deviation of this factor of ratio of auditor identity increases the probability of receiving an opinion of audit with reserve of $107 \%$.

Moreover, the coefficient associated with the variable big is positive of 0.72 and significant with the threshold of $5 \%$ with $(\mathrm{P}=0,017)$. This result is coherent with the results of the studies (Yoke-Kai Chan and Terry S. Walter, 1996, Francis and Stokes, 1986; Nelson et al, 1988 and Kam-Wah Lai, 2013) which showed that the largest audit firms are more likely to qualify an audit report to protect their reputation, and consequently positively influence the probability of having an audit opinion with reservations.

\subsubsection{Opinion of Audit of the Previous Year}

The examination of the table above indicates that the opinion_n1 variable has an odds ratio equal to $4.2>1$, i.e. the decision of certification of an audit opinion with reservations is 4.2 times more likely to occur.

Or that means that the increase in the standard deviation of this factor to have an audit opinion with reservations coming from the previous year increases the probability of receiving an audit opinion with reservations of the current year of $320 \%$.

Moreover, the coefficient associated with the opinion_n1 variable is positive of 1.43 and significant with the threshold of $1 \%$ with $(\mathrm{P}=0,000)$. This result is coherent with the results of the studies (Monroe \& Teh, 1993) which showed that the events of uncertainty which are used to create an audit opinion with reservations in one year $\mathrm{T}$, is able to exist on the level of the following years and consequently positively influence the probability of having an audit opinion with reservations.

\subsubsection{Abnormal Audit Fees}

The examination of the table above indicates that the abfee variable has an odds ratio equal to $1.12>1$, i.e. the decision of certification of an audit opinion with reservations is 1.12 times more likely to occur.

Or that means that the increase in the standard deviation of this factor of unit increases the probability of receiving an audit opinion with reservations of $12 \%$.

Moreover, coefficient associated with abfee variable is positive with 0.12 and nonsignificant with $(\mathrm{P}=0,563)$ This result is not coherent with results of studies (Zanchun, Chun Cai and Jianming Ye, 2010, DeAngelo, 1981, Frankel et al, 2002) which showed that if an auditor receives abnormal fees (i.e. abnormal positive expenses), these abnormal positive expenses influence the dependence of the auditor and thus the deterioration of the audit quality and consequently, negatively influence the probability of having an audit opinion with reservations.

\subsection{Company Size}

The examination of the table above indicates that the size variable has an odds ratio equal to $0.93<1$, i.e. the company size decreases the probability of receiving an audit opinion with reservations of $7 \%$ which shows a 
weak association between these two variables.

Or that means that the increase in the standard deviation of this factor of unit decreases the probability of receiving an audit opinion with reservations of $7 \%$.

Moreover, the coefficient associated with the size variable is negative of -0.07 and nonsignificant with $(\mathrm{P}=$ 0,225). This result is not coherent with the results of the studies (Frost, 1994) which showed that the level of risk increases within large companies can encourage the auditors to be careful in their opinions and consequently positively influence the probability of having an audit opinion with reservations.

\section{Discussion}

Indeed, one notes in the first place a significant and negative association between the probability of receiving an audit opinion with abnormal reservations and outputs and liquidity of the company as well as a significant and positive relationship to the debt. On the other hand, the absence of association with the existence of a loss of result of the company, which shows that the probability of having an audit opinion with reservations is related to the disturbance of the financial situation of the company as to its complexity, since there exists an association between the weight of claim within the company at the time that it is absent with that of stock, the auditor will be more prudent for the certification for its opinion.

In the second place, one finds a strong significant and positive association between the probability of receiving an audit opinion with reservations and the membership to a global area network, we notice that the auditors have an interest in giving a modified opinion in order to protect their reputation, also the existence of a modified audit opinion of the previous year announce that an uncertainly events ableto exist in the following years, but one does not find a relationship bond with the abnormal audit fees which is determined by the positive values of abnormal fee evaluated by the great effort made by the auditor and the better quality of information.

Finally, it is noted that there does not exist any relationship with the organisational factor, the company size.

\section{Conclusion}

In order to formulate his opinion, the auditor must audit the annual financial statements of a firm while behaving competantly and independently. After the business of Enron, confidence granted to the auditor will be on alerte until the appearance of new regulations and their influences on the reinforcement of auditor independence and generally, on audit quality.

Our first section attempts to check the determinants of the opinion formulated by the auditor as a criterion of independence by reflecting on the opinion of the auditor on the internal and external checking of an entity and that this last is used for providing to the users a service of insurance so that they can make decisions like attracting investors and improving the economic and financial situation of the company.

Within the framework of this research, we initially examine our model with that of the literature. The results conform to our expectations with regard to three variables constituting the safe financial statement of the company to the level of the loss announced of the firm one notes the absence of effect and of association as in one of the variables which measures the complexity of the company audited the inventory turnover. On the other hand, the results confirm the assumptions of the second variable of complexity the rotation of the clients' account and those which measure the characteristics of the audit, such as the identity of the auditor, and the expression of the audit opinion with reservations of the previous year, however contrary to expectations, another audit characteristic defined by abnormal fees and company size.

In conclusion, the study of the determinants of the probability of receiving an audit opinion with reservations after the financial scandals shows that the latter is in relation to the amplification of complexity, the level of risk and the disturbance of the financial situation, thus, which is strongly associated with the membership of the auditor in Big 4, and the certified opinion of the previous year, which shows that in this context the auditors may find it beneficial to be more careful in the certification of their opinion which reflects the best quality of the audit, in particular, the independence of the auditor.

\section{References}

Ashton, R. H., Graul, P. R., \& Newton, J. D. (1987). Audit delay and the timeliness of corporate reporting. Working paper. Duke university.

Beck, P., Frecka, T., \& Solomon, I. (1988). A Model of the Market for MAS and Audit Services: Knowledge Spillovers and Auditor-Auditee Bonding. Journal of Accounting Literature, 50-64.

Carol, L., \& Claude, C. (2002). Les vrais problèmes de l'audit. École de Paris du management. 
Chan, K. H., Lin, K. Z., \& Mo, P. (2006). A political-economic analysis of auditor reporting and auditor switches. Review of Accounting Studies, 11(1), 21-48. http://dx.doi.org/10.1007/s11142-006-6394-z

Chen, C. J. P., Chen, S., \& Su, X. (2001). Profitability regulation, earnings management, and modified audit opinions: Evidence from China. Auditing: A Journal of Practice \& Theory, 20(2), 9-30. http://dx.doi.org/10.2308/aud.2001.20.2.9

Chen, C. J. P., Su, X., \& Zhao, R. (2000). An emerging market's reaction to initial modified audit opinions: Evidence from the Shanghai Stock Exchange. Contemporary Accounting Research, 17(3), 429-455. http://dx.doi.org/10.1506/GCJP-5599-QUWB-G86D

Chen, J. T., Douglas, C., Hou, W. X., \& Edward, L. (2013). Executive integrity, audit opinion, and fraud in Chinese listed firms. Emerging Markets Review, 15, 72-91. http://dx.doi.org/10.1016/j.ememar.2012.12.003

Chen, S., Sun, S. Y. J., \& Wu, D. (2010). Client importance, institutional improvements, and audit quality in China: An office and individual auditor level analysis. The Accounting Review, 85(1), 127-158. http://dx.doi.org/10.2308/accr.2010.85.1.127

Chow, C. W., \& Rice, S. J. (1982). Qualified audit opinions and auditor switching. The Accounting Review, 57(2), 326-335.

Craswell, A., Stokes D. J., \& Laughton, J. (2002). Auditor independance and fee dependence. Journal of Accounting and Economics, 33, 253-275. http://dx.doi.org/10.1016/S0165-4101(02)00044-7

Craswell, A. T. (1999). Does the provision of non-audit services impair auditor independence? International Journal of Auditing, 3, 29-40.

DeFond, M. L., \& Francis, J. R. (2005). Audit research after Sarbanes-Oxley. Auditing: A Journal of Practice and Theory.

Dopuch, N., Holthausen, R., \& Leftwich, R. (1986). Abnormal stock returns associated with media disclosures of "subject to" qualified audit opinions. Journal of Accounting and Economics, 8, 93-117. http://dx.doi.org/10.1016/0165-4101(86)90013-3

Elisabeth, B., \& Christophe, G. (2010). Interactions entre les acteurs du processus global d'audit et gouvernance de l'entreprise: Une étude exploratoire. Crises et nouvelles problématiques de la Valeur, Nice: France.

Fang, J. X., \& Hong, J. Q. (2008). Abnormal audit fees and their damage to audit quality. China Accounting Review, 6, 425-442.

Francis, J., \& Stokes, D. (1986). Audit prices, product differentiation and scale economies: Further evidence from the Australian market. Journal of Accounting Research, 24, 383-393. http://dx.doi.org/10.2307/2491141

Frankel, R. M., Johnson, M. F., \& Nelson, K. K. (2002). The relationship between audit fees for nonaudit services and earnings quality. The Accounting Review, 77(Suppl.), 71-105. http://dx.doi.org/10.2308/accr.2002.77.s-1.71

Jean-Guy, D. (2004). Priorité à la sécurité financière et à la fiabilité de l'audit légal en France. The Certified Accountant.

Jong-Hag, C., Jeong-Bon, K., \& Yoonseok, Z. (2006). The Association between Audit Quality and Abnormal Audit Fees, Current Version.

Kam-Wah, L. E. (2013). Audit Reporting of Big 4 Versus Non-Big 4 Auditors: The Case of Ex-Andersen Clients. The International Journal of Accounting, 48, 495-524.

Krishnan, J. (1994). Auditor switching and conservatism. The Accounting Review, 69(1), 200-215.

Lennox, C. (2005). Audit quality and executive officers' affiliations with CPA firms. Journal of Accounting and Economics, 39(2), 201-231. http://dx.doi.org/10.1016/j.jacceco.2003.12.002

Lenormand, G., \& Touchais, L. (2009). Les IFRS améliorent-elles la qualité de l'information financière ? Approche par la value relevance. Comptabilité-contrôle, 15(2), 145-164.

Mark, L. D., \& Clive, S. L. (2011). The effect of SOX on small auditor exits et audit quality. Journal of Accounting and Economics, 52, 21-40. http://dx.doi.org/10.1016/j.jacceco.2011.03.002

Michael, F., Oliver, M. R., \& Xi, W. (2012). How Do Various Forms of Auditor Rotation Affect Audit Quality? Evidence from China. The International Journal of Accounting, 47, 109-138. 
http://dx.doi.org/10.1016/j.intacc.2011.12.006

Monroe, G. S., \& Teh, S. T. (1993). Predicting uncertainty and audit qualifications in Australia using publicly available information. Accounting and Finance, 33(2), 79-106. http://dx.doi.org/10.1111/j.1467-629X.1993.tb00200.x

Pascale, R. (2010). Le contrôle des comptes ou audit...vers plus de contrôle(s). Retrieved from http://www.creg.ac-versailles.fr/IMG/pdf/Le_controle_des_comptes.pdf

Piot, C., \& Schatt, A. (2010). La réglementation de l'audit est-elle dans l'intérêt public: Quelques enseignements du modèle français. Cahier du FARGO (Centre de recherche en Finance, Architecture et Gouvernance des Organisations) $n^{\circ} 1100606$.

Plihon, D. (2007). Les nouvelles normes comptables internationales : une réforme aux implications considerable. L'Économie politique, 36, 74-80.

Raja, A. R., Ahmad, K., \& Anuar, B. K. (2003). Audit delay and the timeliness of corporate reporting: Malaysian evidence. Second Draft.

Wang, Q., Wong, T. J., \& Xia, L. (2008). State ownership, the institutional environment, and auditor choice: Evidence from China. Journal of Accounting and Economics, 46(1), 112-134. http://dx.doi.org/10.1016/j.jacceco.2008.04.001

Yoke-Kai, C., \& Terry, S. W. (1996). Qualified audit reports and costly contracting. Asia Pacific Journal of Management, 13(1), 37-63. http://dx.doi.org/10.1007/BF01739681

Zanchun, X., Chun, C., \& Jianming, Y. (2010). Abnormal Audit Fees and Audit Opinion. Further Evidence from China's Capital Market. China Journal of Accounting Research, 3(1).

\section{Notes}

Note 1. Carol Lambert and Claude Cazes. (2002). Les vrais problèmes de l'audit. École de Paris du management.

Note 2. Pascale Revault. (2010). Le contrôle des comptes ou audit...vers plus de contrôle(s). Retrived from http://www.creg.ac-versailles.fr/IMG/pdf/Le_controle_des_comptes.pdf

Note 3. Jietong Chen, Douglas Cumming, Wenxuan Hou and Edward Lee. (2013). Executive integrity, audit opinion, and fraud in Chinese listed firms. Emerging Markets Review, 15, 72-91.

Note 4. Michael Firth, Oliver M. Rui and XiWu. (2012). How Do Various Forms of Auditor Rotation Affect Audit Quality? Evidence from China. The International Journal of Accounting, 47, 109-138.

Note 5. Yoke-Kai Chan and Terry S. Walter. (April 1996). Qualified audit reports and costly contracting. Asia Pacific Journal of Management, 13(1), 7-63.

Note 6. Michael Firth, Oliver M. Rui and XiWu. (2012). How Do Various Forms of Auditor Rotation Affect Audit Quality? Evidence from China. The International Journal of Accounting, 47, 109-138.

Note 7. Monroe, G. S. and Teh, S. T. (1993). Predicting uncertainty and audit qualifications in Australia using publicly available information. Accounting and Finance, 33(2), 79-106.

Note 8.Zanchun Xie, Chun Cai and Jianming Ye. (2010). Abnormal Audit Fees and Audit Opinion. Further Evidence from China's Capital Market. China Journal of Accounting Research, 3(1).

Note 9. Jong-Hag Choi, Jeong-Bon Kim, and Yoonseok Zang. (2006). The Association between Audit Quality and Abnormal Audit Fees. Current Version.

\section{Copyrights}

Copyright for this article is retained by the author(s), with first publication rights granted to the journal.

This is an open-access article distributed under the terms and conditions of the Creative Commons Attribution license (http://creativecommons.org/licenses/by/3.0/). 